\title{
Case Study: Opportunities and Potential of Cashew Trade Between India and Guinea Bissau 2018
}

\section{Soniyo Yomichan*}

Research Assistant at Habitat International School, Ajman, UAE

*Corresponding Author: Soniyo Yomichan, Research Assistant at Habitat International School, Ajman, UAE.

DOI: 10.31080/ASAG.2020.04.0807

\section{Introduction}

Cashew is an important commodity in the international trade spread across the continents and is a major foreign exchange earner to many countries in the world including India. It provides gainful employment to more than three million people around the world, including about one million in India. Initially, Cashew trees were planted mainly to prevent soil erosion which now has attained the status of a commercial plantation. The world of cashew chain starts with the production of raw cashew nuts, its trade and shipments, the processing of raw nuts to cashew kernels and the marketing and consumption of cashew kernels. The value chain is spread across the globe and involves trading and processing of raw cashew kernels both within the courtiers cultivating crops, countries processing them and consumer countries.

\section{About the Study}

This study is to analyze the trade relation of India and Guinea Bissau in terms of potentiality in cashew production, import, processing and the marketing opportunities. Its being more than 50 years that India and Guinea Bissau are trade partners in raw cashew nut. India is the major cashew growing country in the Asia-Pacific, positioned as the largest producer of raw cashew nut (RCN) globally with 5.5 lakh metric tons per annum. In India, cashew is grown in the peninsular areas of Kerala, Karnataka, Goa and Maharashtra, Tamil Nadu, Andhra Pradesh, Orissa and West Bengal. The country is the single largest producer and exporter of cashews, accounting for $40 \%$ of the global share. It is also the largest importer of RCN globally. Guinea Bissau is the second highest producer in West Africa after Ivory Coast. Many small African countries like Guinea-Bissau are focusing on supply-chain development and competitive pricing to boost their export demand. Ca- shews represent 90 percent of the country's exports and the principal source of income in rural areas. Unfortunately, cumbersome administrative arrangements, weak legal systems, and an absence of credit often lead to high transaction costs for cashew buyers and exporters, which help decrease the farm-gate price of the raw nuts. India is an important trade partner of Guinea-Bissau, and was Guinea-Bissau's largest destination for exports in 2010 and 2011. Later as the domestic production of cashew in India increased the import The main aim of this study is to identify more trade opportunities between Guinea Bissau and India.

\section{Objectives of the Study}

- $\quad$ To study the trade relation between India and Guinea Bissau

- $\quad$ To analyze the processing and marketing sector of cashew nut in India and Guinea Bissau

- Challenges faced in cashew industry and opportunities.

\section{Research Methodology}

It is proposed to adopt a "MULTI-METHODE RESEARCH", using a combination of research methods.

The general frame work of research was

- Data collection (secondary data source)

- Formulating study design

- Data compilation, analysis, interpretation

- $\quad$ Report writing and presentation.

\section{Sources of data}

The entire study was based on secondary data sources, the sources include 
- International journals,

- magazines,

- Cashew Export and Promotion Council-Kerala,

- Global Cashew Council,

- Internet.

Company profile

About global agrisystem

Creating value, addressing changing needs, supporting sustainable growth and ensuring the viability into the future for agriculture, agribusiness and food processing sector.

Global AgriSystem is an agriculture consulting firm providing innovative, sustainable and result driven solutions and services to agriculture, agribusiness, and food processing sector across the value chain. Global AgriSystem has expertise in developing growth strategies, sustainable agribusiness, operational efficiency and integration of stakeholders in value chains that helps create tailormade solutions to bridge the gap between real challenges across the supply chain.

Global AgriSystem works with farmers, traders, government, investors in public and private sector to develop and execute agribusiness, food processing, infrastructure and retail distribution projects worldwide across the agriculture sector. Our aim is to empower our clients to succeed in today's multifaceted and everchanging markets through offering practical solutions, using modern tools and technologies and provide continuously improvement leading to client satisfaction.

\section{History}

Global Agrisystem started Indian operations as Cebeco India Private Limited in 1998, in a joint venture with the Royal Cebeco Group Cooperatives of the Netherlands. Royal Cebeco Group Cooperative, the National Agriculture Holding Cooperative with 29 regional cooperatives and over 100 operating companies had an annual turnover of over 8 billion Euro contributing to over 50\% of Dutch Agriculture. In June 2003, ownership was transferred to the Indian promoters under the Katra Group and Cebeco India was renamed as Global AgriSystem Private Limited. Headquartered in New Delhi, Global Agri system has developed strong and loyal clientele across 10 countries and delivered more than 390 successful project.

\section{Vision}

To revitalize the Indian Agribusiness sector by introducing Technical and Management skills of the highest international standards.

Mission

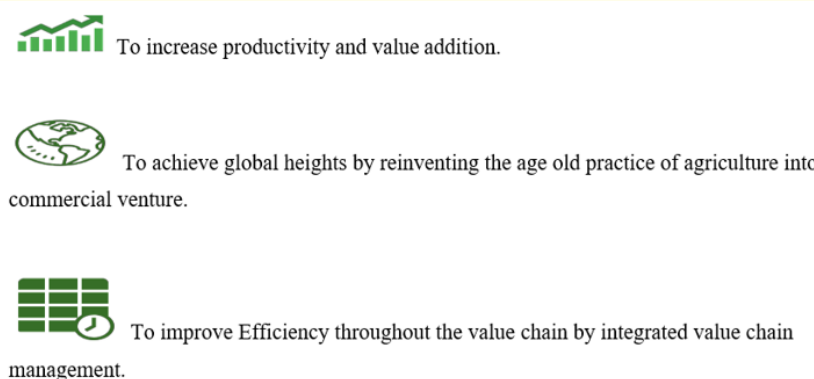

Figure a

\section{Chairman}

Mr. Gokul Patnaik as Chairman leads Global Agrisystem. Mr. Patnaik has worked on developing Indian Agribusiness in various roles including as Chairman, APEDA where export growth was $700 \%$ during his tenure. Mr. Patnaik is credited with creating notable Public: Private Partnerships in the Agribusiness sector including engineering the landmark partnership between PepsiCo and Punjab Agro. Mr. Patnaik continues to be active in various roles in identifying opportunities, farming policy, fostering growth and creating partnerships.

\section{What made us}

For a long time, Indian agriculture has been dogged by low productivity and lower quality of products. The products from Indian agriculture market were not able to compete in the international market, resulting in lower demand and lesser income to the farmers. In contrast, smaller countries like Netherland progressed very well with high productivity, more exports and increased income for farmers. We felt that the problem with Indian agriculture was that it was not being run in the commercial line. Agriculture on a global scale was developing as an enterprise that needs marketing and management inputs. However, In India, this was not being provided to the farmers. Indian farmers had good knowledge about agricultural practices but lacked technological, management or financial skills. We realized that in order to increase productivity and making the farmers earn more we need to provide them 
with knowledge of management, technology, and financial skills. This meant that agriculture must be transformed into agribusiness.

\section{Where's our impact}

With the vision to transform the Indian agriculture Global Agrisystem started its operations in 1998 and brought international technologies and skills to India. This helped Indian farmers and agribusinesses to become more efficient and to earn more with effective and new age agricultural practices. Today Global Agrisystem develops and execute agribusiness, food processing, infrastructure and retail distribution projects throughout the world across the agriculture sector. Empowering clients to succeed in today's multifaceted and ever-changing markets by offering them practical solutions, modern tools, and technologies and provide continuous improvement leading to client satisfaction. Over the years Global Agrisystem has worked with several types of clients such as:

- $\quad$ Farmers

- Traders

- Government

- Investors from public and private sectors.

\section{How we do it}

Headquartered in New Delhi, Global AgriSystem's clientele base spans across 10 countries with 390+ successful international projects under its belt. We promote sustainable practices through our employees, stakeholders, and clients for the well being of our society, world, and ecosystem. We also promote sustainable farming practices that are economically viable, environmentally friendly, strengthen our communities and protect the health of present and future generations. With our expertise in developing growth strategies, sustainable agribusinesses, operational efficiency, and integration of stakeholders in value chains we have created tailormade solutions to bridge the gap between real challenges across the supply chain. Our agriculture methods and practices are based on protecting our earth's natural resources through technology and innovation and efficiently using the land, material, and water in our overall operations. We focus on contributing to the growth of nutritious and healthy crops and foods, creating economic value and enhancing the standard of living and working of the farmers by providing our clients with services like:

- $\quad$ Project Planning and Development

- $\quad$ Project Management and Turnkey Implementation

- $\quad$ Financial services and Partner Search

- $\quad$ Modern Agriculture and Value Chain Development.

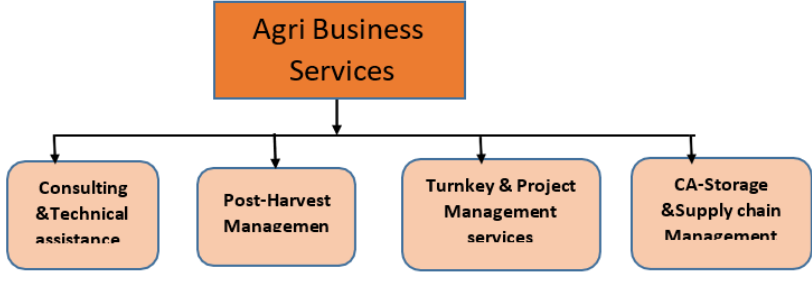

Figure b

GAPL is a full service consultancy in agriculture and food processing areas and offer

- $\quad$ Project and sector studies and blueprints

- Design and promotion of agri infrastructure (market centers, nurseries, processing plants, pack house, agro-complexes, food parks, horticulture parks, dairy farms, CA storage systems)

- Market/commercial surveys and technical assessments.

- $\quad$ Specialty training programs for agribusiness and livelihoods.

- $\quad$ Project funding via credit appraisal and grants, aid and subsidy approvals.

\section{About cashew}

Cashew (Anacardium occidentale L.) is native of tropical America from Mexico to Peru, and from Brazil to also the West Indies. Four centuries ago, the adventurous Portuguese came sailing down the Indian coasts and brought with them the priceless nut tree to control soil erosion on the coasts. Cashew came, conquered and took deep root in the entire coastal region of India. The crop found the Indian soil more homely than its homeland. In the beginning it was mainly considered as a crop for afforestation and soil binding to check erosion. Although its commercial exploitation began from the early 60s, only marginal land and denuded forests were set apart for plantation development.

The word 'cashew' is derived from the Portuguese name for the nut 'caju', which was adopted by them from the native name 'acuju'. The cashew is a low, sprawling evergreen tree (Figure 1a) with a gnarled or twisted trunk, possessing alternate, simple, leathery, oval or obovate glabrous leaves (10 - $12.5 \mathrm{~cm}$ long, $5-10 \mathrm{~cm}$ wide) that are rounded and often notched at the apex (Figure 1a). The wood of the tree exudes a yellow gum. The flowers are borne in clusters on lax terminal panicles at the end of the branches. The 
fruit consists of a soft, shiny, pear-shaped, swollen, juicy basal portion or hypo carp, commonly known as cashew apple. In fact, the swollen peduncle and receptacle is reddish or yellow in color when ripe. The cashew apple bears at its summit a kidney-shaped, single-seeded nut with a hard, grey-green pericarp or shell. This true fruit attains its full size before the enlargement of the receptacle. The shell of the nut contains an acrid juice or sap that causes severe irritation of the skin resulting in painful blisters. The seeds are ex albuminous with reddish brown testa, two large white cotyledons and a small embryo. They are inedible when raw and must be cooked or roasted to drive off the volatile oil before it is opened or shelled.

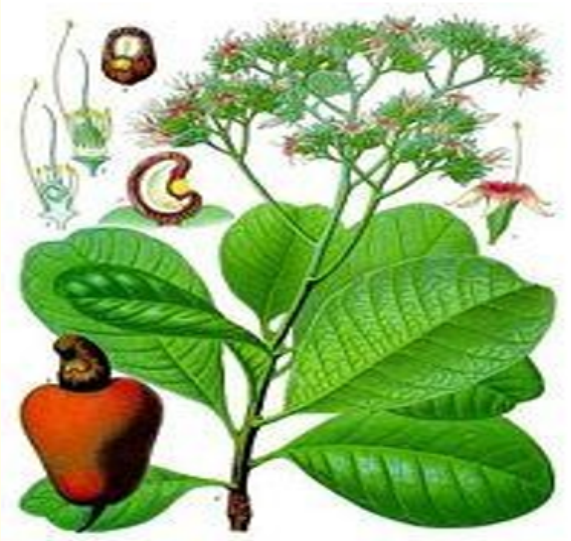

Figure 1: The Cashew leaf, apple, nut.

\section{Cashew products and by-products}

There are three main cashew products that are traded in the international market-raw nuts, cashew kernels, and cashew nut shell liquid (CNSL). A forth product -the cashew apple is generally processed and consumed locally.

\section{Cashew nuts}

Raw nuts are processed to export. Processing of raw cashew nut releases the by-product CNSL that has industrial and medicinal application (figure 2).

\section{Cashew kernels}

It is estimated that 60 percentage of cashew kernels are consumed in the form of snacks and the remaining is processed in confectionery (figure 3).

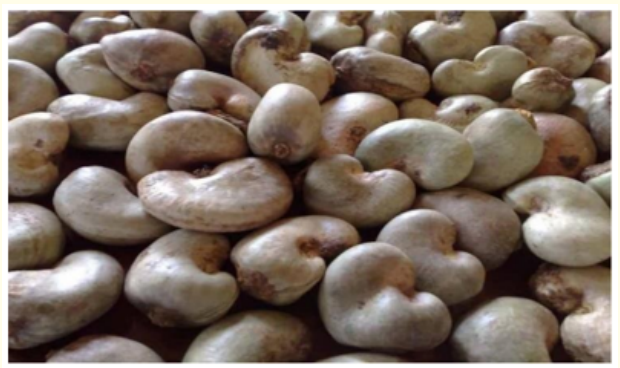

Figure 2: Raw cashew nut.

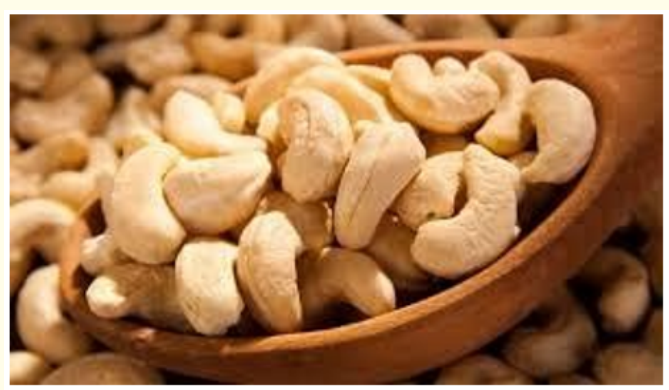

Figure 3: Cashew Nut - Shelled.

\section{Cashew nut shell liquid-CNSL}

CNSL the natural resin found as layer between cashew shell and parchment found over the nut. The liquid is highly heat resistant and is used in braking systems and in paint manufacture, the main component in CNSL is Anacardium.

\section{Cashew apple}

The cashew apple as such is not consumed much, there are certain by-products of cashew apple like Squash, Syrup, RTS, fermented beverages, candied fruit etc.

Cashew kernels, which is a unique combination of fat, carbohydrates and protein, and a source of high energy, are mostly misconceived as not good for health due to the high level of fat contents. Cashew nuts have relatively high fat content (12 g per ounce and 2 g saturated fat), but it is considered "good fat". Like all plant products, they are cholesterol free, Cashew Nuts are sodium free and contain 7 per cent of recommended daily value for dietary protein per serving. They contain small amounts of thiamin, riboflavin, niacin and folic acid. They are good source of iron, phosphorous 
and magnesium. (cashew, the millennium Nut, 2000). Cashew is well balanced in their dietary composition.

The major constituents in cashew kernel are- Moisture 6.9\% - 87.9\%, Protein 21.0\%, Fat 47.0\%, Carbohydrates 22.0 Fiber 1.3 Minerals 2.4 Phosphorous 0.45 Calcium 0.55 Iron $5 \mathrm{mg} / 100 \mathrm{~g}$, Carotene 100 I.U/100g, Vitamin B1 630 mg/100g, Riboflavin 190 $\mathrm{mg} / 100 \mathrm{~g}$, Vitamin C - 170 - $350 \mathrm{mg} / 100 \mathrm{~g}$. There are various recommendations for use of cashew nut consumption for diet and weight loss. Cashew nuts have a high energy density and high amount of dietary fibers, both of which have been credited as having a beneficial effect on weight control, but only when eaten in moderation.

\begin{tabular}{|l|c|c|}
\hline Constituents & Kernel (\%) & Apple (\%) \\
\hline Moisture & 6.9 & 87.9 \\
\hline Protein & 21.0 & 0.2 \\
\hline Fat & 47.0 & 0.1 \\
\hline Carbohydrate & 22.0 & 11.6 \\
\hline Fiber & 1.3 & 0.9 \\
\hline Minerals & 2.4 & 0.2 \\
\hline Phosphorous & 0.45 & 0.01 \\
\hline Calcium & 0.55 & 0.01 \\
\hline Iron & $5 \mathrm{mg} / 100 \mathrm{~g}$ & $0.2 \mathrm{mg} / 100 \mathrm{~g}$ \\
\hline Source: http:/dccd.gov.in/stat.htm \\
\hline
\end{tabular}

Table 1: Constituents in Cashew Kernel and Cashew apple.

\section{Processing of cashew}

The processing of Cashew nuts starts from sizing of raw Cashew nuts and continues up to packaging. The processing involves deshelling of raw cashew kernels to extract the pulpy kernel inside, heat treatment, removal of skin and standardization of the final product. The major steps of processing are given in flow-chart (figure 4).

\section{Drying}

Drying of raw nuts Sun dried in yards, weight loss may vary from $3 \%$ to over $10 \%$ depending on time of harvesting and area of origin. The raw nuts after harvest are sun dried for 2 - 3 days to reduce the moisture from $25 \%$ to 8 - $9 \%$ and stored in gunny bag. The raw cashew nut contains the kernel and papery seed coat (testa); these account for 20 - 30 percent and 2 - 3 percent, respectively, of the raw nut weight; the remaining 70 - 75 percent is the shell.

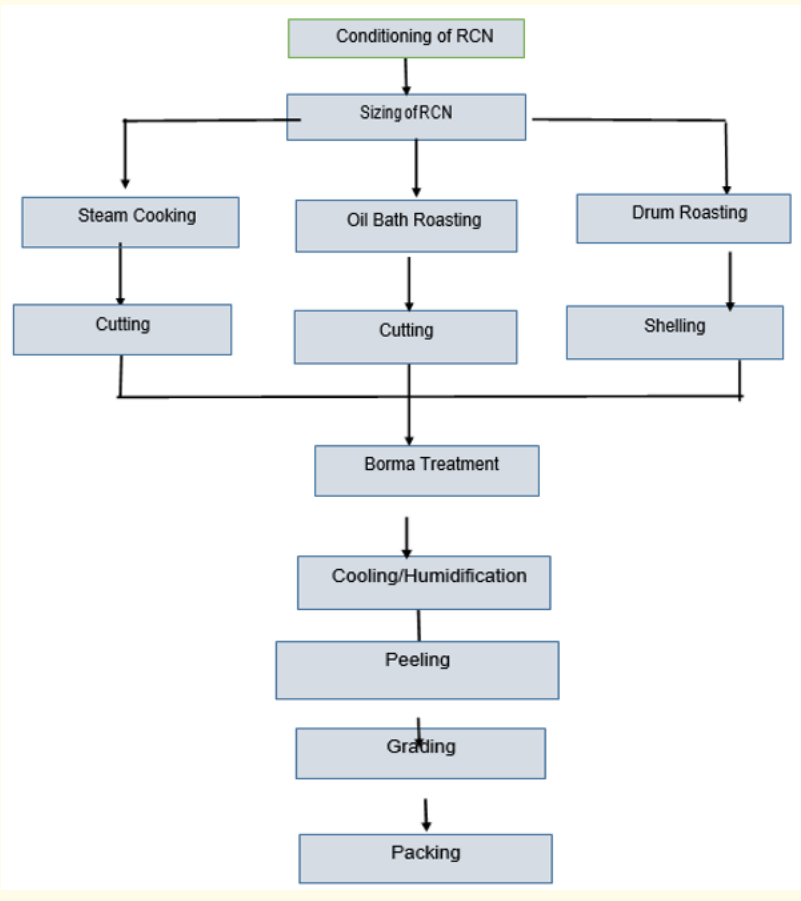

Figure 4: The stages in cashew processing.

\section{Roasting/Steam cooking}

- Drum Roasting: Nuts passed through heated drum where it catches fire for $2 / 3$ minutes.

- $\quad$ Oil Roasting: Dried nuts conditioned with water passed through a hot oil (Cashew Nut Shell Liquid - CSNL) bath by conveyer. The oil in nuts comes out.

\section{Steaming}

This method now a days adopted widely all over the India. The dried nuts are steam cooked. Well dried raw nuts are subjected for steam boiling which is commonly adopted method of nut conditioning in India. The raw nuts are steamed conditioned about 90 - $100 \mathrm{lb}$ pressure for 25 - 30 minutes and then allowed for $24 \mathrm{cool}$ ing.

\section{Decortication}

The de-shelling of cashew is done mainly in three different ways viz. (1) steaming and cutting (2) oil Bath Roasting and Cutting and (3) Drum Roasting and shelling;

- $\quad$ Shelling: Roasted nuts have to be shelled by breaking shells with wooden mallets 
- $\quad$ Cutting: Steamed nuts have to be cut with blades mounted on wooden tables. Raw nuts after conditioning and cooling are to be shelled to remove kernels with the help of hand cum pedal operated shell cutter. After shelling the kernels and shell pieces are separated manually. The kernel after shelling will have moisture content more than 10 percent.

\section{Peeling}

The testa is peeled off and initial grading by wholes, pieces and colour takes place. The peeling process involved removal of testa from the kernel with the help of sharp knife.

Grading

\begin{tabular}{|c|c|c|}
\hline Grade specification & Trade name & Description \\
\hline SW & Scorched Wholes & $\begin{array}{l}\text { Cashew Kernels have been obtained through shelling and peeling. The Kernels } \\
\text { may be light brown, Light ivory in color. }\end{array}$ \\
\hline DW & Dessert Wholes & $\begin{array}{l}\text { Scorched, discolored speckled and shriveled kernels permitted, Fully rancid ker- } \\
\text { nels not permitted. The kernels may show deep black spots. }\end{array}$ \\
\hline $\mathrm{B}$ & Butts & $\begin{array}{l}\text { Cashew Kernels have been obtained through shelling and peeling, Kernels broken } \\
\text { crosswise and naturally attached. }\end{array}$ \\
\hline S LWP & Splits Large White Pieces & $\begin{array}{l}\text { Kernels split naturally lengthwise. Kernels broken into more than two pieces and } \\
\text { not passing through a } 4 \text { mesh } 16 \text { S.W. G. Sieve. }\end{array}$ \\
\hline SWP & Small White Pieces & $\begin{array}{l}\text { Broken kernels smaller than those described as LWP but not passing through a } 6 \\
\text { mesh } 20 \text { S.W.G. Sieve }\end{array}$ \\
\hline DP & Desert Pieces & Kernels broken into pieces, but not passing through a 4 mesh 16 S.W. G. Sieve. \\
\hline SS & Scorched Splits & Kernels split naturally lengthwise \\
\hline SSP & Scorched Splits Pieces & $\begin{array}{l}\text { Broken kernels smaller than those described as S.W.P. but not passing through a } \\
10 \text { mesh } 24 \text { S.W.G. Sieve. }\end{array}$ \\
\hline
\end{tabular}

Table 2: Agmark standards and grade specification of cashew in India.

\section{Global scenario of cashew}

\section{Global outlook on cashew nut}

Cashew processing is a labor intensive job that requires high skill involving dexterity. Traditionally India was the sole processor of cashew nuts in the world in the beginning days of international trade. The western world's efforts to find an alternate supplier encouraged Brazil to start processing in the 1950's. Other small producers like Sri Lanka, Indonesia, East African Countries etc. were also processing cashew in a small way. Later in the early 1990's, the world witnessed the emergence of Vietnam as a strong competitor of India in the international market. In the 2010's, Vietnam took the batten from India as the world's largest exporter of cashew kernels. Mechanization in process added comfort levels to cashew producing countries to go for processing. Heavy mechanization in processing was the success key of Vietnam in the international cashew scenario.

In Asia and Africa, more than $80 \%$ of the cashew cultivation is done by smallholding farms, ranging in size from 0.5 - 5 ha. Medium and large-scale commercial plantations amount to $10-15 \%$ of the total cashew production. Major cashew nut producing countries are Vietnam, Nigeria, India, Côte d'Ivoire and Benin. India and Vietnam are the two major producers and exporters of cashew, accounting for $40 \%$ and $33 \%$ market shares, respectively. Brazil is another major exporter that supplies to the United States. The largest cashew importers in terms of value are Vietnam, India, and 
the US. These countries together account for $85 \%$ of the total cashew import share, which signifies a concentrated nature of import trends. Other importers of cashew kernel are European Union, China, United Arab Emirates, Japan and Saudi Arabia.

Cashew is considered as 'the poor man's crop and the rich man's food'. Rich nations like USA, UK, Europe, Japan and Australia are the major consumers of cashew kernels in the world. Though the exports from processing countries are in the form of plain cashew kernels, the consumption in the above regions are in roasted, salted and other value added forms. A strong market was developed in India during all these days for the broken grades of cashew kernels, which otherwise was not in demand in the international market. But later on, the World witnessed a strong market of cashew kernels in the Middle East and an emerging domestic market in India. Today India is the largest consumer of Cashew kernels in the World.

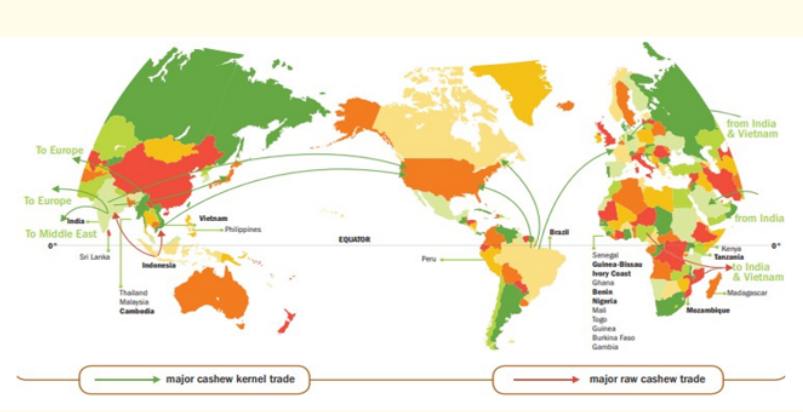

Figure 5: International cashew trade scenario.

Raw cashew production, processing and consumption-global pattern

West Africa and South-Eastern Asia produces almost the same quantity of Raw Cashew Nuts (RCN): around 1,500,000 Metric Tons each and contributes about $90 \%$ to the global production together. East Africa and Brazil are more and more in stage of secondary planation as the region is facing decrease in production mainly because their cashew acreage is old and diseased. Vietnam is the largest producer of cashew nuts in world with an estimated production of 1.24 million MT during 2016-17. Vietnam Ministry of Agriculture tend to highly underestimate its national production and many studies in the cashew sector use the Share of cashew production between 300,000 and 350,000 MT/year while analysis of its import/export balance show the real figure is more between 600,000 and 700000 Metric Tons/year (Source: RONGEAD for
ICA). Even the world agricultural data base FAOSTAT is providing incongruous production figures for important countries like Vietnam and Nigeria.

Currently, the leading producers of cashews are Ivory Coast, India, Nigeria, and Vietnam. Cashew nuts production almost reached 790,000 metric tons in the 2017 - 2018, which is a 32\% growth in the last decade. West Africa produces about $46 \%$ of the global cashew nuts, with Cote d'Ivoire producing $48 \%$ of the crops followed by Guinea-Bissau and Nigeria. Other top producers include Vietnam, India, and Tanzania (Source:worldatlas.com). Cashew production of India as estimated by the Cashew Export Promotion Council of India was 850000 MT in 2015 while industry players estimated it to be between 700000 and 725,000 MT in 2015-16 and 680,000 MT in 2016-17.

\begin{tabular}{|l|c|c|}
\hline Sl. no & Country & Production (MT) (2016- 17) \\
\hline 1 & Vietnam & 1237300 \\
\hline 2 & Nigeria & 836500 \\
\hline 3 & India & 680000 \\
\hline 4 & Cote D'Ivore & 450000 \\
\hline 5 & Benin & 170000 \\
\hline 6 & Philippines & 132541 \\
\hline 7 & Guinea & 130000 \\
\hline 8 & Tanzania & 122274 \\
\hline 9 & Indonesia & 117400 \\
\hline 10 & Brazil & 80630 \\
\hline
\end{tabular}

Table 3: Major Cashew Producing Countries (2016-17).

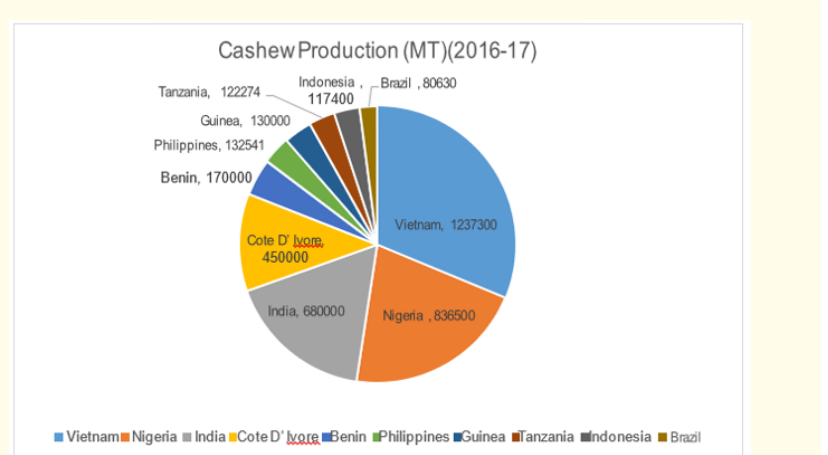

Figure 6: Graph showing major cashew producers in world and quantity (MT) produced in 2016-17. 
Nigeria, Vietnam, India, Cote D'Ivore, and Benin are the global leaders in terms of importing raw cashew for processing and value addition. The cashew importers are the countries which process the cashew. India, Vietnam and Brazil are the three main country that process more than $90 \%$ of the global raw cashew produced.

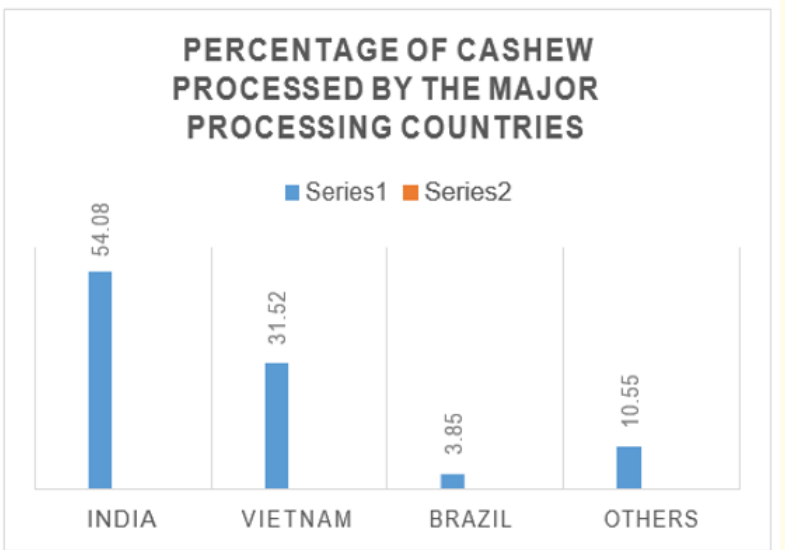

Figure 7: Percentage of cashew processed by top processing countries.

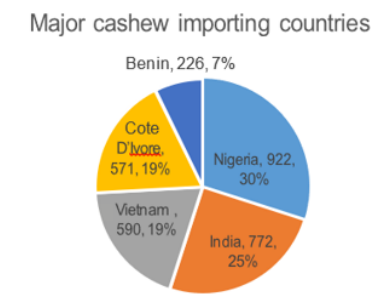

$=$ Nigeria $=$ India $=$ Vietnam $=$ CoteD'lluere $\|$ Benin

Figure 8: Major Cashew Importing Countries in World.

The processing industry of cashew is not spread in same proportion as its production. The processing of cashew is centered mainly in Vietnam, India and Brazil. These three courtiers process $89 \%$ of total world production together. The distribution of processing industry on the basis is of volume handled is as depicted below pie diagram. India stands first in cashew processing and it process $54.08 \%$ of the global cashew, Vietnam process around $31.52 \%$ of the global cashew produced and Brazil process $3.85 \%$. cashew processing -global scenario \% of cashew processing

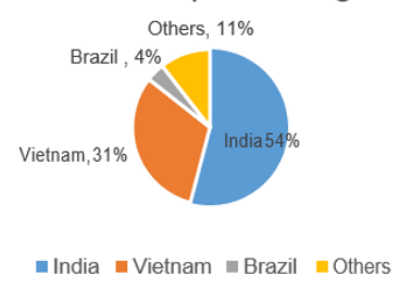

Figure 9: Cashew processing countries (2016-17).

India stands first in cashew consumption, and it consume more than $66 \%$ of cashew it process. USA and Germany are in second and third position in cashew consumption (Source: World atlas).

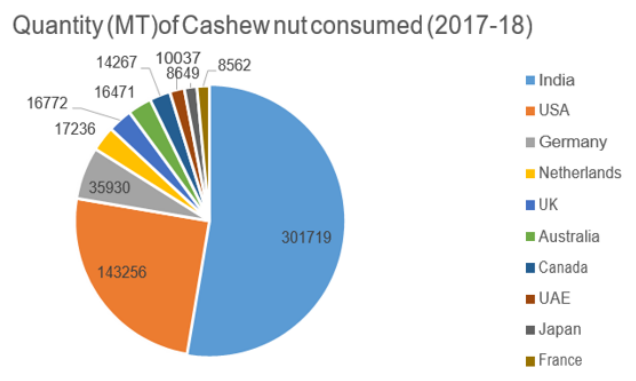

Figure 10: Top ten cashew nut consumers in world (2017-18).

\begin{tabular}{|l|c|c|}
\hline Sl. No & Country & Quantity (MT) \\
\hline 1 & India & 301719 \\
\hline 2 & USA & 143256 \\
\hline 3 & Germany & 35930 \\
\hline 4 & Netherlands & 17236 \\
\hline 5 & UK & 16772 \\
\hline 6 & Australia & 16471 \\
\hline 7 & Canada & 14267 \\
\hline 8 & UAE & 10037 \\
\hline 9 & Japan & 8649 \\
\hline 10 & France & 8562 \\
\hline
\end{tabular}

Table 4: Top Ten cashew consuming countries (2017-18). 
India and the cashew industry

Indian cashew production, importing, processing and consumption pattern

Commercial cultivation of cashews in India started in the 1960s in Goa and Kerala and now cashew is grown as cash crop by farmer's peninsular region of country. As a pioneer in the cashew trade globally, India draws a considerable amount of foreign exchange through cashew trade.

- India is the major cashew growing country in the AsiaPacific region, positioned as the largest producer of raw cashew nut (RCN) globally with 7.7 lakh metric tons per annum (2016-17).

- $\quad$ The country is the single largest producer and exporter of cashews, accounting for $23 \%$ of the global share. It is also the largest importer of RCN globally, with around 8 lakh metric tons of average annual imports, followed by Vietnam.

- In India, cashew is grown in the peninsular areas of Kerala, Karnataka, Goa and Maharashtra, Tamil Nadu, Andhra Pradesh, Orissa and West Bengal.

India was the First country to establish cashew processing as an industry and international trade commodity. Majority of the cashew producing countries count on India as their export destination for both processing and consumption. India has the advantage of having highly skilled labor backed with strong domestic market for broken cashew kernels - which otherwise does not has international demand be sold in the international market, making cashew processing in India more feasible than any other part of the world. More than a million workers, majority of whom are women from the socially and economically backward communities of rural India earn their livelihood through this industry and approximately four million farmers depend on cashew cultivation.

India was the processing hub of cashew nuts in the world that apart from her own production of raw cashew nuts, a lion share of production of raw nuts in the rest of the world was imported into India and after processing here, the processed kernels were exported to different parts of the world. The premier position enjoyed by India in this market looks shaky today as India is facing strong competition in the international market than ever before. The competitor countries are gaining potential on both fronts of Production as well as Processing by introduction of improved farming and mechanized means of processing. Cashew nut producing countries are improving the status of their manufacturing industry strategically by means of mechanization to compensate the lack of skilled labor which has brought them in commanding position in global cashew trade. As Indian processing industry is heavily dependent on imports raw cashew nuts which is becoming more and more challenging as countries like Vietnam and Brazil are strengthening their processing industry posing pressure on Indian Export.

This had a double effect that on one side it affected the raw material sourcing for India while on the other side these counties turned out to be the competitors to India in the international market by offering these processed cashew kernels, which otherwise would have been the produce of India. Also, these countries have become able to export their broken kernels to Indian market at competitive prices making trade more lucrative for others, but more tough for India.

\section{Production scenario of India}

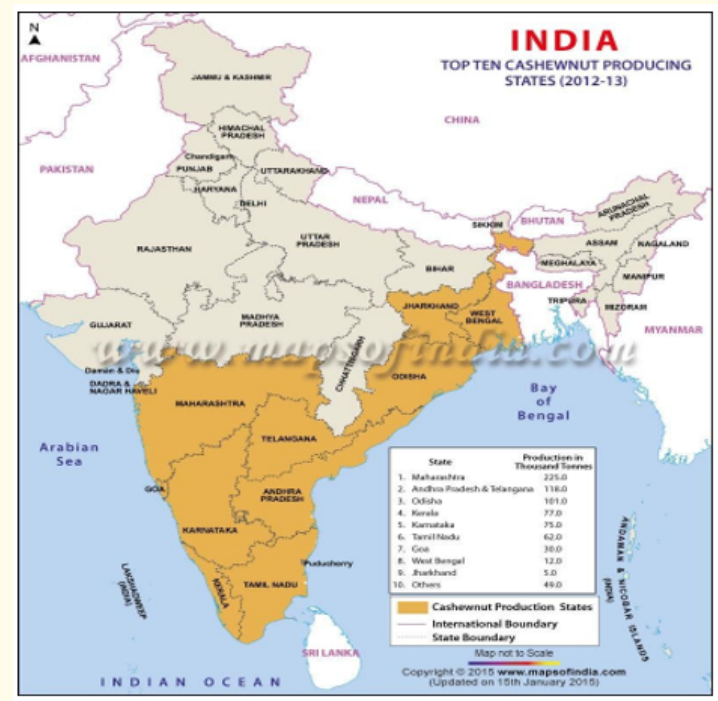

Figure 11: Major states of India producing cashew.

In India there are 9 states that are involved in cashew production, Maharashtra, Kerala, Tamil Nadu, Karnataka, Andhra Pradesh, Odisha, Telangana, Jharkhand, West Bengal.

In India Maharashtra stands first in cashew production, Andhra Pradesh, Kerala, Karnataka, Odisha are the other states which produce cashew in large quantity and all these sates process the cashew produced by them, along with that these states process the 
cashew which is imported from other countries. Kerala stands first in processing cashew, as if it produce only $13 \%$ of the total cashew produced in India but it process more than what it produce because of the processing plants and there capacities.

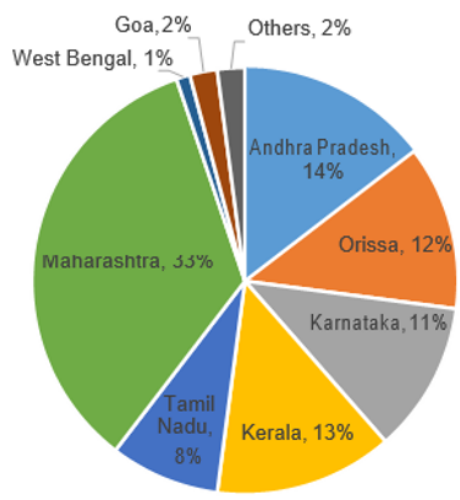

$$
\begin{aligned}
& \text { \# Andhra } \\
& \text { Pradesh } \\
& \text { — Orissa } \\
& \text { \# Karnataka } \\
& \text { @ Kerala } \\
& \text { - Tamil }
\end{aligned}
$$

Figure 12: Major cashew producing states and there production status in 2016-17.

Area and production of cashew in India

India is one of the major producer of cashew in world. We are positioned third in cashew production. The production volume and in our nation is increasing over the years, and the acreage is also increasing as the crop is being introduced in non-cashew growing regions of Bihar, Jharkhand and Odisha etc. Maharashtra produce about $33 \%$ of the total cashew production in India, Andhra Pradesh, Kerala, Odisha and Karnataka produce 14\%, 13\%, 12\% and $11 \%$ respectively. Over the years, domestic cashew production has increasing steadily. The cashew production in India has increased by.... \% from 704274 MT (2012-13) to 779335 MT (201617) (Table a).

Over the years due to advancement in mechanization, cashew processing industry in India has been grown, As a result of growth in processing industry India started importing cashew from other major producing nations. Indian cashew import is more or same the domestic production, after processing and value addition it is again exported. Cashew industry and exports account for a large percent of income and foreign exchange to India (Table 5).

The majors countries from which India import cashew are Ivory Coast, Guinea Bissau, Tanzania. Guinea Bissau is a country from which India import more than $90 \%$ of cashew for processing and exporting. The importing rate towards India depends on the domestic production and international cashew price.

\begin{tabular}{|l|l|l|l|l|l|l|l|l|l|l|}
\hline \multirow{2}{*}{ STATES } & $\mathbf{2 0 1 2 - 1 3}$ & $\mathbf{2 0 1 3 - 1 4}$ & \multicolumn{2}{l}{$\mathbf{2 0 1 4 - 1 5}$} & \multicolumn{2}{l|}{$\mathbf{2 0 1 5 - 1 6}$} & \multicolumn{2}{l|}{$\mathbf{2 0 1 6 - 1 7}$} \\
\cline { 2 - 11 } & $\mathbf{A}$ & $\mathbf{P}$ & $\mathbf{A}$ & $\mathbf{P}$ & $\mathbf{A}$ & $\mathbf{P}$ & $\mathbf{A}$ & $\mathbf{P}$ & A & P \\
\hline Maharashtra & 18200 & 224640 & 184200 & 242610 & 186200 & 235000 & 186200 & 220000 & 186200 & 256610 \\
\hline Andhra Pradesh & 183950 & 118144 & 184950 & 100420 & 185450 & 100000 & 185570 & 95500 & 185570 & 111390 \\
\hline Orissa & 163910 & 100840 & 166910 & 85710 & 180410 & 85500 & 182910 & 80500 & 182910 & 93895 \\
\hline Karnataka & 121880 & 74640 & 124110 & 80610 & 124710 & 80500 & 125860 & 73000 & 126710 & 85147 \\
\hline Kerala & 84880 & 76960 & 84930 & 83120 & 84530 & 80000 & 87010 & 72000 & 87285 & 83980 \\
\hline Tamil Nadu & 136420 & 62400 & 139420 & 67390 & 140420 & 67000 & 141330 & 58000 & 141330 & 67650 \\
\hline Goa & 57470 & 29950 & 57970 & 32350 & 58170 & 32000 & 58170 & 28000 & 58170 & 32659 \\
\hline West Bengal & 11000 & 12060 & 11160 & 13030 & 11360 & 13000 & 11360 & 12000 & 11360 & 12960 \\
\hline Jharkhand & 11500 & 4640 & 14500 & 1200 & 14830 & 4500 & 14830 & 5000 & 14830 & 5830 \\
\hline Others & 27000 & 24200 & 38090 & 30120 & 41120 & 27920 & 41750 & 26300 & 41125 & 29214 \\
\hline Total & 955210 & 704274 & 1006240 & 736560 & 1027200 & 725420 & 1034990 & 670300 & 1035490 & 779335 \\
\hline
\end{tabular}

Table a 


\begin{tabular}{|l|c|c|c|c|c|c|}
\hline & \multicolumn{2}{|c|}{ 2011-2012 } & \multicolumn{2}{c|}{ 2012-2013 } & \multicolumn{2}{c|}{ 2013-2014 } \\
\hline Countries & QTY & VALUE & QTY & VALUE & QTY & VALUE \\
\hline Ivory Coast & 181265 & 1058.45 & 268306 & 1367.11 & 209201 & 1058.09 \\
\hline Guinea Bissau & 136384 & 1046.20 & 109627 & 764.90 & 114701 & 676.32 \\
\hline Tanzania & 60011 & 442.18 & 145107 & 1052.26 & 111935 & 892.17 \\
\hline Benin & 122301 & 791.37 & 154834 & 871.53 & 103979 & 608.16 \\
\hline Ghana & 128361 & 787.62 & 83810 & 465.89 & 96343 & 524.83 \\
\hline Others & 181504 & 121300 & 130681 & 810.00 & 135197 & 804.00 \\
\hline Total & 809825 & 5338.64 & 892365.23 & 5331.74 & 771356 & 4563.99 \\
\hline
\end{tabular}

Table 5: Cashew import towards India.

Indian cashew processing Industry

India stands first in Cashew Nut Processing and India is the third largest consumer of cashew nuts in the world, India processes around 1.59 million tons of cashew nuts every year though it produces only around half of the quantity that it processes. The first commercial cashew processing unit was set up in Kollam in the mid-1920. Export volumes picked up only after the introduction of airtight tins infused with carbon dioxide in the mid-1950s.

Indian cashew process industry has been gradually developed into labor-intensive industry because of high organization.

- The processing industries in India are scattered in many states as it provide employment to over 0.5 million people and out of that $95 \%$ are women.

- $\quad$ At present there are 4000 processing units across India.

Indian cashew export scenario

Indian Cashew industry is well-established. The major items traded in cashew market is cashew kernels and the consumption of cashew kernels are mainly in the form of 'broken' and 'pieces' that are widely used as ingredients in food items. The domestic

\begin{tabular}{|l|c|c|c|c|c|}
\hline States & $\begin{array}{c}\text { Process- } \\
\text { ing Units } \\
\text { (Units) }\end{array}$ & $\begin{array}{c}\text { Capacity } \\
\text { (000'MT) }\end{array}$ & \multicolumn{3}{|c|}{ Utilization (000' MT) } \\
\hline & & & Local & Import & Total \\
\hline Tamil Nadu & 453 & 400 & 294 & 225 & 519 \\
\hline Kerala & 487 & 600 & 67 & 320 & 387 \\
\hline $\begin{array}{l}\text { Andhra } \\
\text { Pradesh }\end{array}$ & 184 & 100 & 92 & 20 & 92 \\
\hline Karnataka & 276 & 300 & 45 & 0 & 65 \\
\hline Goa & 51 & 50 & 21 & 0 & 21 \\
\hline Maharashtra & 2260 & 50 & 20 & 0 & 20 \\
\hline Odisha & 216 & 100 & 11 & 0 & 15 \\
\hline NE states & 27 & 10 & 25 & 0 & 11 \\
\hline West Bengal & 46 & 8 & 8 & 0 & 8 \\
\hline Total & 4000 & 1610 & 574 & 565 & 1138 \\
\hline
\end{tabular}

Table 6: Total processing plants in India state wise and total utilization of plant capacity.

consumption of cashew Kernels in India was earlier negligible and has increased over the years. Now the present domestic consumption of cashew kernels are more than export quantity of processed cashew.

\begin{tabular}{|l|c|c|c|c|c|c|}
\hline & \multicolumn{2}{|c|}{ Cashew Kernel } & & \multicolumn{3}{c|}{ Cashew Nut Shell Liquid } \\
\hline Year & $\begin{array}{c}\text { Qty } \\
\text { (MT) }\end{array}$ & $\begin{array}{c}\text { Value } \\
\text { (Rs. Crs) }\end{array}$ & $\begin{array}{c}\text { Value } \\
\text { (US \$ Mls) }\end{array}$ & $\begin{array}{c}\text { Qty } \\
\text { (MT) }\end{array}$ & $\begin{array}{c}\text { Value } \\
\text { (Rs. Crs) }\end{array}$ & $\begin{array}{c}\text { Value } \\
\text { (US \$ Mls) }\end{array}$ \\
\hline $2014-14$ & 114791 & 5058.73 & 863.15 & 9480 & 38.61 & 6.38 \\
\hline $2014-15$ & 118952 & 5432.85 & 88.59 & 10938 & 55.81 & 9.13 \\
\hline $2015-16$ & 96346 & 4952.12 & 756.40 & 11677 & 57.59 & 8.80 \\
\hline $2016-17$ & 82302 & 5168.68 & 771.00 & 11422 & 44.00 & 6.56 \\
\hline $\begin{array}{l}2017-18 \\
\text { (Apr-Oct '17) }\end{array}$ & 52218 & 3632.37 & 563.33 & 4835 & 18.78 & 2.91 \\
\hline
\end{tabular}

Table 7: Export scenario of cashew in India. 
India export the processed cashew across the globe. The major countries to which India export cashew are UAE, USA, Saudi, Japan, Netherlands, Germany. During the year 2013-14 UAS was the major importer of cashew kernel from India with a quantity of 33898 MT and it decreased to $9780 \mathrm{MT}$ in 2017-18. UAE became the country that imports major proportion of processed cashew kernels from India in 2017-18, $10053 \mathrm{MT}$.

\begin{tabular}{|l|c|c|c|c|c|c|}
\hline Countries & $\mathbf{2 0 1 3 - 1 4}$ & $\mathbf{2 0 1 4 - 1 5}$ & $\mathbf{2 0 1 5 - 1 6}$ & $\mathbf{2 0 1 6 - 1 7}$ & $\mathbf{2 0 1 7 - 1 8}$ & \\
\hline & QTY (MT) & QTY (MT) & QTY (MT) & QTY (MT) & QTY (MT) & Value (Crs) \\
\hline UAE & 17421 & 23904 & 18537 & 18556 & 10053 & 719.12 \\
\hline USA & 33898 & 30643 & 22661 & 17515 & 9780 & 679.96 \\
\hline Saudi & 7195 & 6636 & 7535 & 7441 & 4432 & 316.83 \\
\hline Japan & 6702 & 7413 & 7826 & 6434 & 5196 & 358.80 \\
\hline Netherlands & 9918 & 9349 & 2720 & 4891 & 5324 & 356.13 \\
\hline Germany & 2808 & 4724 & 2597 & 2449 & 2079 & 143.76 \\
\hline Belgium & 2122 & 2601 & 2777 & 2362 & 1382 & 93.40 \\
\hline Korea & 2221 & 3193 & 2296 & 2271 & 806 & 56.10 \\
\hline Spain & 3089 & 2384 & 2916 & 2140 & 1489 & 105.67 \\
\hline France & 2963 & 2958 & 2961 & 1907 & 1346 & 96.22 \\
\hline Others & 26454 & 25147 & 20245 & 16336 & 10331 & 706.38 \\
\hline Total & 114791 & 118952 & 96346 & 82302 & 52218 & 3632.37 \\
\hline
\end{tabular}

Table 8: Country wise export of cashew nut kernel from India.

It can be inferred from the chart that India produce 7.8 Lakh Tons and we import 8.7 Lakh Tons of cashew from other cashew producers, then the total 17.5 Lakh Tons of cashew is processed and after processing $23 \%$ is the output. Out of the 3.75 Lakh Tons processed 2.25 Lakh Tons of cashew is domestically consumed and 1.25 Lakh Tons of processed cashew is exported from India.

- The consumption is mostly in north India where cashew is part of the Mediterranean diet.

Cities like Delhi, Mumbai, Jaipur and Lucknow are the major cashew consumers in India.

Volume proposition of cashew in India

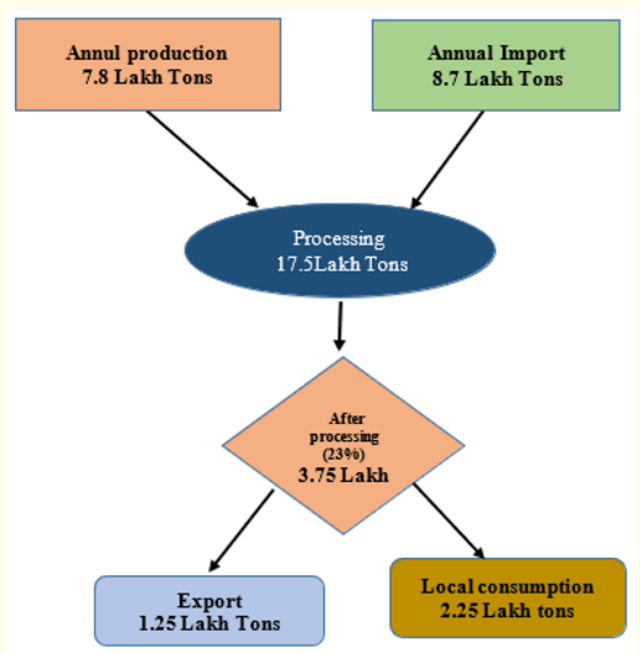

Figure 13: Volume Proposition of cashew in India.
Major challenges faced by Indian Cashew Industry

The major challenges faced by the Indian cashew trade industry are stringent policies regarding cultivation, Lack of availability of labor, competition from other crops and competitive pricing of crops.

\section{Processing and packaging}

International trade of cashew-nut is depend of two things one is cashew nut processing and other is packaging. Inefficient processing practices reduce the quality of cashew kernel at large extent especially broken of cashew kernel which has very less price in market compare to whole cashew kernel and are not eligible for export.

The processing industry is $95 \%$ depend on manual work forcemany cashew nut processing units closed because they are not getting sufficient work force.

\section{Lack of raw material}

Heavy dependence of India on imports of raw cashew nuts has put the producing countries in a commanding position that today India is at the mercy of these producing countries to source raw cashew nuts for processing.

The consumption of cashew kernels had increased worldwide including India. Indian consumption had grown up along with Indian exports. The Indian cashew production has been stagnant for the past few years with output ranging $6-7$ lakh tones while the country's processing capacity has expanded to 2 million tones (2017-18). 


\begin{tabular}{|l|c|c|c|}
\hline States & $\begin{array}{c}\text { Processing Units } \\
\text { (Number) }\end{array}$ & $\begin{array}{c}\text { Capacity } \\
\text { (000'MT) }\end{array}$ & Total \\
\hline Tamil Nadu & 453 & 400 & 519 \\
\hline Kerala & 487 & 600 & 387 \\
\hline Andhra Pradesh & 184 & 100 & 92 \\
\hline Karnataka & 276 & 300 & 65 \\
\hline Goa & 51 & 50 & 21 \\
\hline Maharashtra & 2260 & 50 & 20 \\
\hline Odisha & 216 & 100 & 15 \\
\hline NE states & 27 & 10 & 11 \\
\hline West Bengal & 46 & 8 & 8 \\
\hline Total & 4000 & 1610 & 1138 \\
\hline Source: CEPCI (2016-17). & & \\
\hline
\end{tabular}

Table 9: Processing Units in India and capacity utilization.

It can be interpreted from the table that in India, across different states there are 4000 processing units in India and altogether has $1610000(\mathrm{MT})$ processing capacity, But the utilization of the processing unit is 1138000 MT that is only $70.6 \%$ of units are utilized and the rest $30 \%$ of the processing units in India is not properly utilized or are not in working. As the cashew consumption in India (2.25 Lakh tons) is more than Indian cashew exports (1.25 Lakh tons). For processing 17.7 Lakh tons of cashew there are 4000 units with 1610000 (MT) capacity, but the available capacity of plants are not utilized.

Guinea Bissau and the cashew industry

Cashew production and exporting pattern

Guinea-Bissau is located in West Africa, between 10 $59^{\prime}-12^{\circ}$ $20^{\prime} \mathrm{N}$ and $13^{\circ} 40^{\prime}-16^{\circ} 43^{\prime} \mathrm{W}$. According to the National Institute of Statistics and Census, in 2014 1,514,451 inhabitants populated an area of $36,125 \mathrm{~km} 2$. Outside of the capital, Bissau, the population is mainly rural and very few services and infrastructures are in place.

Agriculture is the engine of Guinea-Bissau's economy. The sector relies mainly on cashew nuts and rice, along with the subsistence production of food crops. Cashews represent 90 percent of the country's exports and the principal source of income in rural areas. Although other crops are grown to an extent, they tend not to be exported. Cashew is traded for rice, with considerable reliance on a barter system. The cashew sector is thus at the core of both economic performance and poverty reduction. Cashew production accounts for $11.9 \%$ of the country's GDP and $87.7 \%$ of its exports. Consequently, it is a major source of economic activity and revenue both for the state and the population at large. Four-fifths of the labor force, and contributes to more than 90 percent of the country's export earnings through cashew nut exports. Over the past three decades, the production of cashew nuts has increased substantially.

\section{Cashew production scenario of Guinea Bissau}

Guinea-Bissau is now the seventh-largest producer of cashew nuts ( 6 percent of the world cashew production) after India, Vietnam, Brazil, Ivory Coast, and Tanzania. Guinea Bissau is the second highest producer in West Africa after Ivory Coast. In 2015 the country's output stood at 220,000 MT amounting to $6.6 \%$ of total world production.

Raw cashew nuts are Guinea-Bissau's main export. Cashew exports have been increasing over the past decade, especially when accounting for smuggling. Harvesting cashew is the most dominant economic activity among Bissau-Guinean households. A limited amount of the harvested cashew is processed, mostly for domestic consumption: the cashew apple is turned into wine and the cashew nut is roasted and de-shelled. Yet the vast majority of cashew production is geared to the export of raw cashew kernel. Between 2000 and 2014, official exports increased from about 80 thousand to about 140 thousand metric tons.

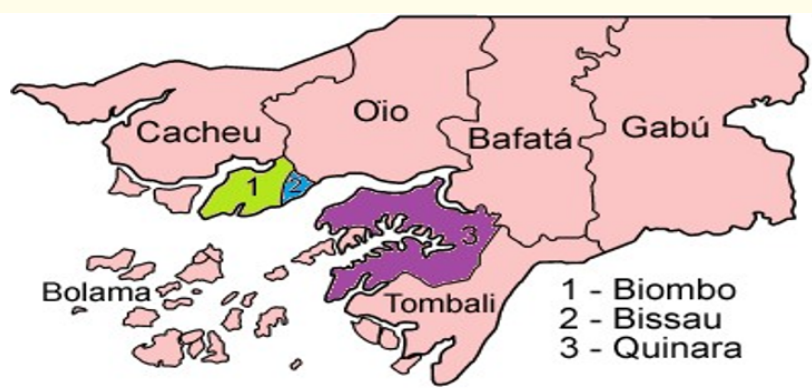

Figure 14: Major Cashew producing areas of Guinea Bissau.

The efficiency of the cashew sector has probably been affected by this lack of investment, if only in terms of transport costs. Similarly, private investments suffered from the lack of adequate financing mechanisms, which is one of the reasons why GuineaBissau produces and exports raw cashews instead of moving up the value chain. 


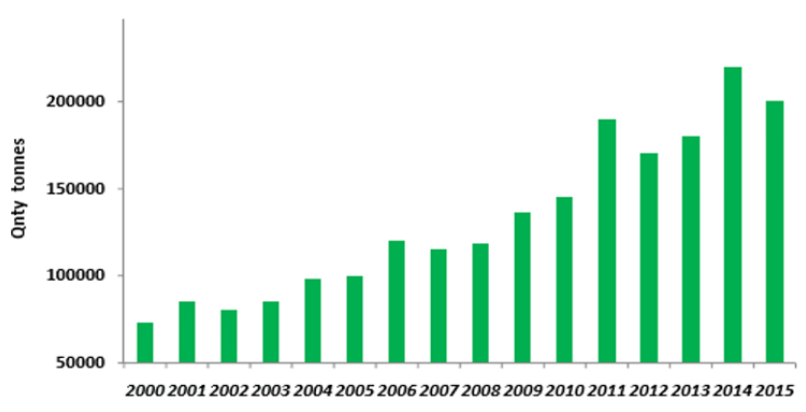

Figure 15: Raw Cashew production pattern in Guinea Bissau.

Raw Cashew Nut production of Guinea Bissau is increasing as shown in graph above. The production was highest during 2014 and 2011 in Guinea Bissau.

The export of Raw Cashew Nut kernel is also increased from 98,000 MT in 2005 to 179,000 MT in 2015

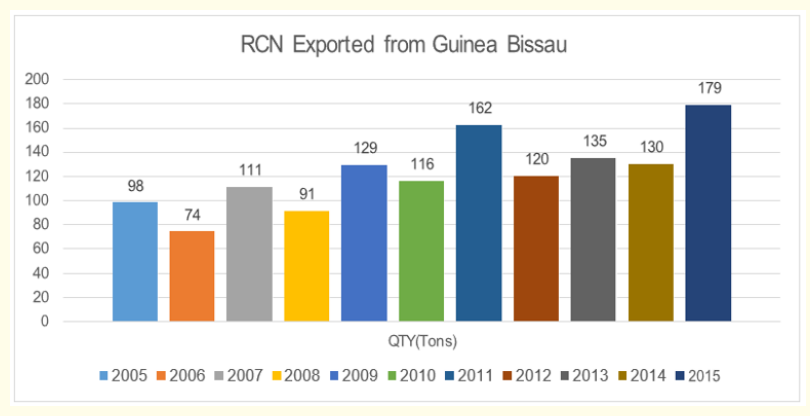

Figure 16: RCN Export from Guinea Bissau.

Major challenges faced by the cashew industry of Guinea Bissau

Cumbersome administrative arrangements, weak legal systems, and an absence of credit often lead to high transaction costs for cashew buyers and exporters, which help decrease the farm-gate price of the raw nuts.

\section{Investment challenges}

The efficiency of the cashew sector has probably been affected by lack of investment, not only in terms of transportation costs but also in the input sector. The financial system in Guinea-Bissau is very much limited to the banking sector and there is only four banks. There are currently four banks operating there, which can be considered as a small market. Private investments suffered from the lack of adequate financing mechanisms, which is one of the reasons why Guinea-Bissau produces and exports raw cashews instead of moving up the value chain.

Regulation, taxes and duties barriers

It is found that an increase in farm-gate prices, which could be achieved through a reduction in transaction and financing costs, could help to reduce poverty.

The same would likely be true for a reduction in export taxes. In contrast, an increase in export taxes on raw cashew exports in order to promote the creation of processing facilities could, at least in the short run, affect farmers negatively.

\section{Trade relationship between India and Guinea Bissau}

India is an important trade partner of Guinea-Bissau, and was Guinea-Bissau's largest destination for exports in 2010 and 2011. Guinea-Bissau is one of the largest exporter of raw cashew nuts, and the sector accounts for $90 \%$ of the country's income and employs over $80 \%$ of its labor force making it vital to its economy. India is the largest importer of unprocessed cashews from Guinea-Bissau, Almost $98 \%$ of the cashew crop is exported to India for processing.

Since 2011, India has increased its domestic cashew production and reduced imports from Guinea-Bissau. India's decision to slash imports of cashews in 2012 resulted in a cashew nut export crisis in Guinea-Bissau. Bilateral trade between Guinea-Bissau and India totaled US\$ 212.64 million in 2015-16, recording a growth of $26.46 \%$ over the previous fiscal. India exported $\$ 14.47$ million worth of goods to Guinea-Bissau, and imported \$198.17 million.

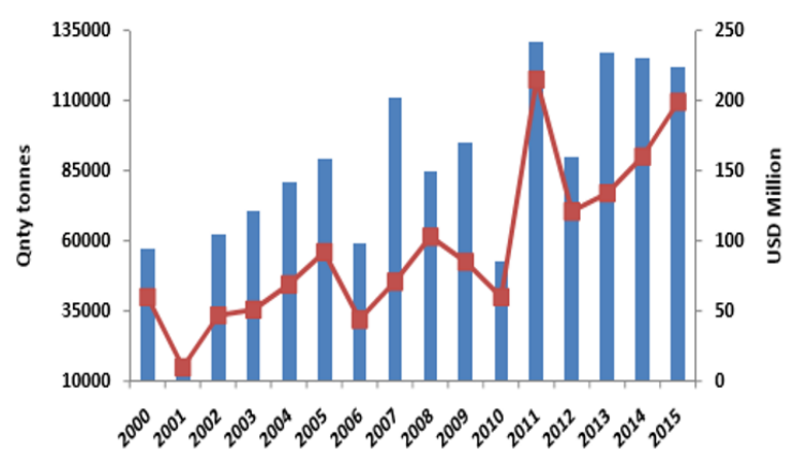

Figure 17: Cashew trade between India and Guinea Bissau. 
Why India prefer guinea Bissau RCN

India is the largest importer of unprocessed cashews from Guinea-Bissau, Almost 98\% of the total cashew crop of this African country is exported to India for processing particularly to Kerala, for processing. The major ports through which cashew is imported from Guinea Bissau to India are Tuticorin Sea, Mangalore Sea and
Cochin sea ports. Tuticorin Sea port is the main port through which India's cashew export and import takes place (Table 10).

Bilateral trade between Guinea-Bissau and India totaled US\$ 212.64 million in $2015-16$, recording a growth of $26.46 \%$ over the previous fiscal. India exported $\$ 14.47$ million worth of goods to Guinea- Bissau, and imported \$198.17 million.

\begin{tabular}{|c|c|c|c|c|c|}
\hline Date & India Port & Value(USD) & Qty & Unit & Unit Price( USD) \\
\hline 6-Sep-16 & Mangalore Sea & 622788.94 & 361213 & KGS & 1.72 \\
\hline 6-Sep-16 & Tuticorin Sea & 506017.25 & 309440 & KGS & 1.64 \\
\hline 6-Sep-16 & Tuticorin Sea & 440015.22 & 262668 & KGS & 1.68 \\
\hline 6-Sep-16 & Tuticorin Sea & 431099.88 & 257790 & KGS & 1.67 \\
\hline 6-Sep-16 & Tuticorin Sea & 425394.52 & 253981 & KGS & 1.67 \\
\hline 6-Sep-16 & Tuticorin Sea & 383827.33 & 202701 & KGS & 1.89 \\
\hline 6-Sep-16 & Tuticorin Sea & 363614.98 & 214660 & KGS & 1.69 \\
\hline 6-Sep-16 & Mangalore Sea & 315435.38 & 198005 & KGS & 1.59 \\
\hline 6-Sep-16 & Mangalore Sea & 271765.52 & 157622 & KGS & 1.72 \\
\hline 2-Sep-16 & Tuticorin Sea & 253532.93 & 146341 & KGS & 1.73 \\
\hline 6-Sep-16 & Tuticorin Sea & 225777.61 & 133845 & KGS & 1.69 \\
\hline 2-Sep-16 & Tuticorin Sea & 194458.84 & 105000 & KGS & 1.85 \\
\hline 2-Sep-16 & Tuticorin Sea & 188948.24 & 99290 & KGS & 1.90 \\
\hline 2-Sep-16 & Tuticorin Sea & 188285.62 & 101710 & KGS & 1.85 \\
\hline 5-Sep-16 & Cochin Sea & 186723.32 & 101.38 & MTS & 1841.82 \\
\hline 2-Sep-16 & Tuticorin Sea & 183887.52 & 100000 & KGS & 1.84 \\
\hline 2-Sep-16 & Tuticorin Sea & 183887.52 & 100000 & KGS & 1.84 \\
\hline 2-Sep-16 & Tuticorin Sea & 175968.04 & 98668 & KGS & 1.78 \\
\hline 6-Sep-16 & Tuticorin Sea & 168606.22 & 103130 & KGS & 1.63 \\
\hline 5-Sep-16 & Cochin Sea & 166623.95 & 100280 & KGS & 1.66 \\
\hline 5-Sep-16 & Cochin Sea & 165959.32 & 99880 & KGS & 1.66 \\
\hline 2-Sep-16 & Tuticorin Sea & 156219.03 & 95000 & KGS & 1.64 \\
\hline 2-Sep-16 & Tuticorin Sea & 156219.03 & 95000 & KGS & 1.64 \\
\hline 6-Sep-16 & Cochin Sea & 155377.18 & 86.44 & MTS & 1797.51 \\
\hline 3-Sep-16 & Tuticorin Sea & 82870.5 & 49760 & KGS & 1.67 \\
\hline 6-Sep-16 & Tuticorin Sea & 64069.08 & 36580 & KGS & 1.75 \\
\hline 3-Sep-16 & Calcutta Sea & 60912.77 & 35.33 & MTS & 1724.11 \\
\hline 6-Sep-16 & Tuticorin Sea & 56581.71 & 34630 & KGS & 1.63 \\
\hline 6-Sep-16 & Mangalore Sea & 53718.25 & 33720 & KGS & 1.59 \\
\hline 3-Sep-16 & Calcutta Sea & 29789.27 & 17.29 & MTS & 1722.92 \\
\hline
\end{tabular}

Table 10: Glimpse of Raw cashew Kernels from Guinea Bissau. 
Guinea Bissau produces superior quality raw cashew nuts in terms of out terms of process ability, taste and texture amongst other African origin cashew kernels, but the size of the cashew is relatively small. The nuts are of small size but are harder and thus can withstand the processing stress giving higher yield of whole shelled nuts per unit volume of raw cashew kernels. Thus GB cashew are preferred by Indian Processors as the processing is done either manually or lesser sophisticated equipment. Smaller portion of broken makes the business more profitable for processor using GB cashew nuts as raw material more profitable.

Future outlook of the crop market - India and Guinea Bissau

Guinea-Bissau 's Cashew nuts hold very competitive position in terms of consistent raw material production and transformation yields potential (processing output). The trade challenge lies in terms of processing/industrial activities, transport and commercialization (institutional environment).

- If Indian companies do not quickly act in West Africa particularly Guinea Bissau for procurement of RCN, the Western firms and European counties will control the \$300-million strong Cashew Nut market of Guinea-Bissau.

- India plays vital role in economic stability of the country and hence shall increase its involvement in well doing of GB's cashew value chain by providing inputs for more organized production and procurement of cashew.

- $\quad$ European, American and Arab companies have keen interest in Guinea-Bissau's cashew - and that Libya had started three processing plants in the country.

- If we establish a company in Guinea Bissau, we can have free access to the big markets, which numbers 300 million inhabitants in the case of ECOWAS, and 100 million in the case of the monetary union.

- India led the production of cashews of 172,719 metric tons (2016-16, kernel basis), which represented the 23.00 percent of global production. In India cashew is being grown in an area of 10.27 lakh hectares with a total production of 7.25 lakh MT of raw nuts and unit area productivity of $706 \mathrm{~kg} / \mathrm{ha}$.

- India stands first in Cashew Nut Processing and India is the third largest consumer of cashew nuts in the world, India processes around 1.59 million tons of cashew nuts every year though it produces only around half of the quantity that it processes.

\section{Way-forward}

If both of these countries join together, there will be a revolution in cashew industry. This may result in development of new Hybrid varieties, increased production, maximum utilization of processing plants, and earning the foreign exchange.

SWOT-analysis: Cashew trade between India and Guinea Bissau

\begin{tabular}{|c|c|}
\hline Strength & Opportunities \\
\hline $\begin{array}{l}\text { India and Guinea Bissau are } \\
\text { major producers of quality } \\
\text { rich cashew kernels } \\
\text { Guinea Bissau's cashew is } \\
\text { known for its quality and yield } \\
\text { on processing. } \\
\text { India has the best advanced } \\
\text { mechanization in cashew } \\
\text { processing industry } \\
\text { Guinea Bissau exports its } 90 \% \\
\text { of cashew produced and there } \\
\text { are many nations to buys } \\
\text { Guinea's cashew } \\
\text { India and Guinea together } \\
\text { forms the leaders in RCN } \\
\text { production, processing and } \\
\text { exporting. }\end{array}$ & $\begin{array}{l}\text { Since India and Guinea Bissau } \\
\text { are major RCN producers, } \\
\text { there joint effort can make } \\
\text { them as the world leaders in } \\
\text { RCN production and process- } \\
\text { ing. } \\
\text { India can establish new } \\
\text { cashew processing industry in } \\
\text { Guinea so that the whole world } \\
\text { market can be easily covered. } \\
\text { The yield per quantity and } \\
\text { quality on processing is } \\
\text { maximum for Guinea Bissau } \\
\text { cashew, so the production of } \\
\text { cashew has to be increased } \\
\text { and HYV cashew has to be } \\
\text { planted. }\end{array}$ \\
\hline Weakness & Threats \\
\hline $\begin{array}{l}\text { The consumption rate of } \\
\text { cashew in India is more than } \\
\text { exporting rate. } \\
\text { Lack of mechanization in } \\
\text { Guinea Bissau } \\
\text { The processing of cashew is } \\
\text { cumbersome process. } \\
\text { Lack of labor availability } \\
\text { Transportation problem and } \\
\text { Investment. }\end{array}$ & $\begin{array}{l}\text { Other major cashew produc- } \\
\text { ing countries } \\
\text { Adoption of mechanization in } \\
\text { Nigeria, Brazil, Ivory Cost etc. } \\
\text { European and Arab countries } \\
\text { implementing new cashew } \\
\text { processing plants. }\end{array}$ \\
\hline
\end{tabular}

Table b

\section{Conclusion}

India is an important trade partner of Guinea-Bissau, and was Guinea-Bissau's largest destination for exports in 2010 and 2011. Guinea-Bissau is one of the largest exporter of raw cashew nuts, 
and the sector accounts for $90 \%$ of the country's income and employs over $80 \%$ of its labor force making it vital to its economy. India is the largest importer of unprocessed cashews from GuineaBissau, Almost $98 \%$ of the cashew crop is exported to India for processing [1-9].

Guinea-Bissau revealed a very good competitive position in terms of raw material production and transformation yields potential (processing output), But very difficult situation in terms of processing/industrial activities, transport and commercialization (institutional environment).

Cashew accounts for more than 90 percent of Guinea-Bissau's export earnings. Almost the entire crop is exported to India, particularly to Kerala, for processing. Since more than $90 \%$ of Guinea Bissau's cashew is processed in India- so we should also think about starting production and processing ventures there.

- Guinea Bissau produces the best quality raw cashew nuts in terms of out tern in the whole of Africa, but the size of the cashew is relatively small.

- $\quad$ Due to the high yield in processing, Guinea Bissau nuts are much preferred worldwide.

\section{Bibliography}

1. Luís Catarino., et al. "Cashew cultivation in Guinea-Bissau risks and challenges of the success of a cash crop". (2014).

2. Patil. "Problems and Prospects of Cashew-nut Industry of Kolhapur District”. Shivaji University, Kolhapur, India (2012).

3. Walkar., et al. "Performance of Cashew Export from India" (2005).

4. http://worldbank.org/macroeconomics

5. UNCOMTRADE, Eurostat, USDA, Indian Customs, Vietnam Ministry of Agriculture, Vietnam Customs Data bases - N'Kalô Service Data base and Bulletins - African Cashew Alliance data base - Audouin Sarah, Gazull Laurent, "Les dynamiques d'un système d'innovation à travers le prisme des diffusions spatiales. Le cas de l'anacarde au Sud-Ouest du Burkina Faso". L’Espace géographique 1/2014 (2014): 35-50.

6. http://cepci.in

7. Cepci-Annual report (2016-17).
8. file:///C:/Users/user/Documents/global/Cashew\%20 nut\%20processsing/Cashew_nuts_final_presentation

9. https://www.researchgate.net/publication/241280141

\section{Assets from publication with us}

- Prompt Acknowledgement after receiving the article

- Thorough Double blinded peer review

- Rapid Publication

- Issue of Publication Certificate

- High visibility of your Published work

Website: www.actascientific.com/

Submit Article: www.actascientific.com/submission.php

Email us: editor@actascientific.com

Contact us: +919182824667 